\title{
Javanese-Language Advertisements in 1935-1953: The Construction of National Ideas
}

\author{
Diah Mardiningrum Joyowiwdarbo1, Atin Fitriana², Dwi Puspitorini ${ }^{3}$ \\ 1,2,3 Javanese Study Program, Faculty of Humanities, Jalan Prof. Dr. Selo Soemardjan Kampus \\ Universitas Indonesia Pondok Cina, Beji, Depok, West Java 16424 \\ E-mail: atinfitriana@gmail.com
}

\begin{abstract}
Advertisement is a form of presentation to communicate about goods or services to public. The development of technology has transformed the form of advertisement. Current advertisements are mostly photos and videos and are easily found through electronic media and printed media. Meanwhile, in the advertisements that's written in Javanese from 1935 to 1953 , it was found that advertisements were presented in the form of narratives paragraphs with few images or illustrations. Moreover, there are many advertisements constructed by presenting the names of independence movement leaders, and Indonesian language. The advertisements were displayed on Panjebar Semangat Magazine in 1935-1953; the period before and after Indonesia's independence. Therefore, it is necessary to do research to reveal how national ideas are constructed in advertisements. The research is carried out with the approach of implicature theory to find out the hidden national ideas beyond the sentences in advertisement. 130 advertisements are collected and there are 20 advertisements that contain national ideas, namely the advertisement of books, pins, and kethoprak products. The results of research shows that national ideas in advertisements lie under declarative and imperative sentences that explicitly convey the product excellence and a persuasion. The national ideas are presented through the use of names of the leaders of independence movement, the national language, and nationalistic vocabularies such as 'bangsa', 'nusa', 'nasional', and 'Indonesia'. The hidden national ideas reflect Javanese culture who are not direct in conveying a message.
\end{abstract}

Keywords: Javanese language; Javanese Culture; Advertisement; Implicature, National Ideas 


\section{INTRODUCTION}

An advertisement is often found in various media such as electronic and printed media which functions to introduce goods or services to the societies. Nowadays, advertisements are easily found due to advancements of technology. Unlike the era when the technology was still limited; many people did not have TV and internet access. Hence societies relied on printed media as the advertisers, such as magazines. As the consequences, the advertisements were generally in a form of narration. As the invention of internet and smartphone technology used by societies. Advertisements are not only be presented through printed media and electronic media, especially TV and radio, but also through the news app used by societies and tend to contains photos and videos. The messages delivered through advertisements are also not limited to products offerings, but also about politics and culture. According to [1], advertisement is all kind of forms of presentation and promotion of ideas, goods or non-personal services that are paid by certain sponsor.

In the Javanese-language advertisements, interesting matters were found; the advertisements were mostly in the form of narrative paragraph and images were rarely used. As in the Javanese-language advertisement of pin product published in 1940; there are sentences "Soepaja kita teroes éling marang semangaté pemimpin kita. Saiki kita wis bisa gawé penitiinsigne saka metal (perak-alpacca). Portrété Dr.Soetomo, Ir. Soekarno, R.A. Kartini”. If observed closely, the use of words is not only about the products, but also to raise some figures, such as Dr. Soetomo, Ir. Soekarno, R.A. Kartini; independence movement figures. The construction of such advertising sentences is found in many advertisements wrote in Javanese language from 1935 to 1953.

Many previous studies on advertising had been carried out under the discussion of discourse and pragmatic analysis. Research on advertising with discourse analysis had been conducted by [2] entitled "Discourse Studies of Advertisement on Short Message Service". This research shows that an utterance may be categorized as expressive and directive in advertisement. A pragmatics research had also been conducted by [3] entitled "The Representation of Nationalism in Corporate Advertising of PT. Gudang Garam TBK". This research analyzed the representation of nationalism contained in television advertisements by corporate PT. Gudang Garam TBK. The result shows that advertisement presents company's positive image as a nationalist company. A research on national identity in advertisement has been carried out by [4] entitled "National Identities on Display, The Role of Advertisements in the Management of Polish National Identity". The results of the study show that the advertisements purpose is actually to promote products and services, but it also succeeds to promote national identities to society. Based on these previous studies, research on national ideas in advertisement becomes a prominent research to be held. Javanese-language advertisement hasn't been widely studied. Therefore, it is urgent to conduct a research on national identities in Javanese-language advertisements. This research aims to find out the national ideas constructed in Javanese-language advertisements from 1935 to 1953.

This research uses a pragmatic approach with implicature theory. Implicature is an unsaid, and implied information yet being communicated in the utterance [5], [6] explains that implicature is a component of the speaker's meaning serves an aspect of the speaker's intention but it is not said. Therefore, implicature is when the intended meaning is hidden behind the spoken words. According to [7], implicature or "implying" is a concept that refers to a matter that is implicated in an utterance (asserted) [8], [9] concludes that implicature is the implicit 
meaning of speech or in other words implicature is the intention of a speech but is not expressed directly. Based on the statement above, implicature is the meaning conveyed implicitly because it is not presented explicitly in the speech. Referring to the delivery, Javanese usually convey a message indirectly. This is performed to avoid open conflict and maintain harmony in the society. This habit is called ethok-ethok "pretending", so that the real meaning can be hidden beyond.

\section{METHOD}

The data used are Javanese-language advertisements published in 1935-1953. The advertisements were published in Panjebar Semangat magazine stored in the National Library of the Republic of Indonesia. The total number of data collected are 130 advertisements. After all data are collected, the data are then be categorized based on advertisements which contain the names of independence movement figures, the words 'bangsa', 'bahasa Indonesia', 'Indonesia', and 'nasional'. The total source of advertisement data after being categorized are 20 advertisements and then being analyzed by using implicature theory to reveal the national ideas in it.

\section{RESULT AND DISCUSSION}

Based on the advertisements collected, the products advertised include books, kethoprak art performances, calendars, drugs, balms, dentists, pins, shoes, bicycle shops, and flowers. These products are the manifestation the influence of west cultures, namely colonialism. This is because of the intensive interaction between Javanese culture and western culture, which further encourages indigenous people to imitate western culture [10]. In the 1936 shoe ads text, there was an influence of western culture in term of language; such as the use of Dutch Schoenmakerij 'shoemaker'. According to [10] the indigenous people believed that Dutch language skills would increase the prestige, because it corresponds the expectations of the indigenous elites who graduated from European schools. Moreover, Dutch was an intellectual symbol at that time. In addition to the influence of language, it was also found the influence of western culture towards recreation and food on book product advertisements. The book advertised discusses sports and Dutch food recipes. In the late 1920s, indigenous people were accustomed to follow western recreational activities, especially sports [10]. The production of Dutch food recipe books shows that the Javanese also consumes Dutch food. Although there were western culture's influences on products yet there were no Javanese ads that advertise western arts. Otherwise, it was found that there were many advertisements of kethoprak art performance; which is a Javanese art. This is in accordance with the statement [10], that indigenous' imitation of western cultures do not always get a positive judgement from the society.

From the advertisements discussed, it is found that the meaning of sentences in the advertisement is delivered explicitly and implicitly. Explicitly, the advertisements are displayed to convey the intention of persuading people to choose and buy the product by telling the products' excellence. This explicit feature is characterized by the use of suffix -a on the verb moendhoet which means transaction/activities of exchanging money with goods. The use of verb makes an imperative sentence, and in Indonesian it means 'buy'. In addition, the advertising sentence also explicitly tells the product excellence advertised by using declarative and imperative sentences. Products that are often advertised for its excellence are books and kethoprak art performances. The book advertised is said to have advantages such as the 
completeness and the well-structured contents, the books' benefit for the society, best-selling books on the market, and the physical quality of books and uphold the element of nationalism. The advantages portrayed in Kethoprak advertising sentence are the actors' skill in performing scenes and singing the songs, actors' popularity, and information about the goodness of the play. Besides the advertisement of book and kethoprak art performance that convey product excellence, there are also other products advertisements such as drug, balms, pins, bicycle shops and dental clinic.

Based on the implicature analysis conducted on 20 advertisements, the national ideas are reflected in the presence of the names of independence movement figures, the word "Bahasa Indonesia", and the sentences that represent "nationality". The meaning of national ideas lie under the sentences in the advertisements of products' excellence of book, pin, and kethoprak art performances.

\subsection{The Name of Independence Movement Figures}

In the advertisements of book and pins, some names of figure are presented as product excellence. In the advertisements of pins, the images of independence movement figures are used as an advantage of products' marketing. Meanwhile in book products advertisement, it lies in the content that discusses the independence movement figures. The following are examples of book advertisements (1) and pins advertisement (2).

(1) Jaikoe boekoe kang gedhe banget, oekoeran 23 X 30 c.m. kandele 76 katja, toer rinengga ing gambar-gambare para pemimpin, Dr. Tjiptomangoenkoesoemo, Ir. Soekarno, nganti Mr. Latuharhary sarta isi pitoetoer lan wedjangan kang paedah, kang ora bakal mamboe (wadhang) disimpen lawas.

'It's a very large book, dimension 23 X 30 c.m. 76 pages, and decorated with the pictures of leaders, Dr. Tjiptomangoenkoesoemo, Ir. Soekarno, and Mr. Latuharhary, also completed with useful advices that will last forever.'

The sentences in advertisement above was published in 1937; in the period before Indonesia's independence. The sentence tells the product excellence which is decorated with images of leaders. Those leaders are Dr. Tjiptomangoenkoesoemo, Ir. Soekarno, and Mr. Latuharhary. Dr. Tjiptomangoenkoesoemo is one of the founders of Boedi Oetomo - a modern organization in Indonesia in 1908, and he's one of the founders of the first political party in the colonial era named Indische Partij in 1912. Ir. Soekarno at that time was known for his struggle as an activist from Jong Java of Surabaya, and also the founder of the Algemeene Club 1926 as the embryo of the Indonesian National Party which was founded later in 1927. Mr. Latuharhary was the chairman of Serikat Ambon (Ambon Union) in 1928. By referring to the year of publication and the name of the figures in the advertisement, it shows that there was a spirit of nationalism from the society before independence. Indonesian nationalism initially emerged as an answer to colonialism. The experience of suffering as a colonized resulted in the spirit of solidarity as a community who must rise up and live to become an independent nation [12]. The following is an example of a pins product advertisement that mention the names of independence movement figures, 
(2) Soepaja kita teroes éling marang semangaté pemimpin kita. Saiki kita wis bisa gawé peniti-insigne saka metal (perak-alpacca). Portrété Dr.Soetomo, Ir. Soekarno, R.A. Kartini.

'In order for us to keep remembering to the spirit of our leaders. Now we can make insigne pins from metal (alpaca silver). The pictures of Dr.Soetomo, Ir. Soekarno, R.A. Kartini.

Sentence (2) is displayed on pins product advertisements in 1940 (pre-independence period). The nation's leaders who are mentioned in the sentence are Dr. Soetomo, Ir. Soekarno, R.A. Kartini. The pictures of these three leaders are compiled with the product advertised. Dr. Soetomo is the founding father of Budi Utomo, the first movement organization of Indonesia in 1908, Ir. Soekarno is a figure in the national movement too, and R.A. Kartini is a figure in the national movement of Indonesian women who brought out the position of women from underdevelopment. The presence of the independence movement figures name as a product excellence in the period before independence shows the efforts of the community in presenting the spirit of nationalism.

\subsection{Indonesian Language as the Advantages}

In the advertisements, the book's excellence is indicated by the use of "Bahasa Indonesia" and "basa kita dhewe". This shows that the use of Indonesian language is something that people are proud of. Indonesian language has acted as the language of unity because it was declared at the Youth Oath in 1928; in the sentence 'We the sons and daughters of Indonesia, respect the language of unity, Indonesian language.' Here is an example of an advertising sentence that represents the language of unity.

(3) Basané Indonésia, ning iya runtut, ija gampang, dimangertèni, mentes, pepak lan maremakè.

'The language is Indonesian, it's coherent, easy to understand, brief and insightful, complete, and satisfying. '

The advertisement of book (3) is displayed in 1953; after the declaration of Indonesia's independence. In the advertisement, it can be seen that the use of Indonesian language in the book is taken as the product excellence. The use of Indonesian as a product excellence in advertising after independence shows that through advertising, the advertisers want to show the pride of the people with the presence of Indonesian language as a language of unity in advertisement.

\subsection{The Vocabularies of Nationalism}

In the advertisement sentences before the independence period, it was found the use of the vocabularies of bangsa 'nation', nasional 'national', Indonesia 'Indonesia', nusa 'island', and negara 'country'. These vocabularies are related to nationality and shows the importance of ideas about Indonesia. In advertisement sentences, some of the vocabularies are constructed in the form of persuasion and descriptions of product excellence. The products that use the vocabularies of nationalism in advertisements are kethoprak art performances and book. The following is an example of advertisements that uses the vocabularies of nationalism, 
(4) Ajo, loer, rame-rame, ngiras njokong Gedhong kita...kětoprak,, SRIWOELAN" kang main ing Pendhapa Gedong Nasional.

'Come on, brothers, come together, support our House. Ketoprak,, SRIWOELAN "which will be performed at the hall of National Building.'

The sentence above was displayed in 1935 in kethoprak art advertisement. The word Gedhong refers to the building where kethoprak performance is held. The name of the building is mentioned in the advertisement as Pendhapa Gedhong Nasional 'the hall of National Building'. By using the verb njokong 'to help, it can be inferred that the ads sentence appeals to the readers to support the existence of the building. This is because the high number of audience of Kethoprak event held in the building means that the existence of the building is also saved. The use of the word 'National' in the name of the building shows the importance of the building nationally. The characteristics of nationalism are socialized to society through advertisement. In addition to the presence of the word Nasional 'National' in the advertisements for kethoprak art performance, the word that shows national ideas are also found in book advertisements. The following is an example of a book product advertisement that uses the words "nusa" and "bangsa",

(5) Boekoe poenika para poetri prajogi simpěn, sagěda dados panggoerandaning penggalih toemrap poetri ingkang anggajoeh santosaning tekad, kangge ngoehorakěn bangsa toewin noesa.

'This book should be kept by women, so that it becomes a guide for women who want to achieve good determination to unite the country and nation.'

This ads sentence (5) is displayed in 1936 before the declaration of independence. In the sentence there are the words "Nusa" and "Bangsa". The word "nusa" which means 'the island' shows the geographical characteristics of the Indonesia that consists of many islands. The ads appealed to women to own the books that were marketed because the advertised book was useful as a guide for the women to realize their national vision that is to unite the nations. Based on the ads sentence, the word "nusa" and "bangsa" in the advertisement are used as a national identity. Through the advertisement of the book, the spirit of nationalism is also displayed in the advertisement.

Based on the explanation above, the national ideas presented secretly in Javanese advertising sentences show ethok-ethok 'pretending' habits of the Javanese. Javanese expresses the spirit of nationalism indirectly to maintain harmony in society. It is assumed that this was done because in 1935-1953 Indonesia was still not completely separated from the colonizers. Although in 1945 Indonesia had officially declared itself to be an independent state, but Indonesia had not completely escaped from Netherlands. The encouragement of the spirit of nationalism is carried out secretly and well-covered in the main theme of advertisement. This was done by introducing goods and services through the information on product excellence and persuasive sentences.

\section{CONCLUSION}

Based on the discussion about Javanese advertisement, the national ideas in the advertisement sentences in 1935-1953 were constructed through the presence of the names of independence movement figures, national language 'Indonesian', and national vocabulary, such as 'bangsa', 'nusa', 'nasional', and 'Indonesia'. The construction of national ideas is found in the 
advertisements of books, pins, and kethoprak art performances which are presented through declarative and imperative sentences. In its delivery, national ideas are hidden beyond the excellence of the products. In addition, related to the national idea, advertisements from 1935 1953 were not only used as a means to promote a product or service, but also used as a means to convey the spirit of nationalism. The construction of the national ideas beyond the Javaneselanguage advertisement also shows the Javanese culture 'ethok-ethok'; to convey the message impliedly.

\section{REFERENCES}

[1] P. Kotler, Manajemen Pemasaran. Jakarta: PT. Prenhallindo, 1999.

[2] R. Riani, "Kajian Wacana Iklan Pada Pesan Singkat (SMS)," Ranah J. Kaji. Bhs., vol. 4, no. 1, pp. 47-60, 2015.

[3] Ria Angelia Wibisono, "Representasi Nasionalisme Dalam Iklan Korporat Pt. Gudang Garam Tbk," J. Ilm. Scriptura, vol. 2, no. 1, pp. 38-47, Feb. 2008.

[4] A. Lubecka, "National identities on display. The role of advertisements in the management of Polish national identity," in Estonia and Poland: Creativity and tradition in cultural communication, L. Laineste, D. Brzozowska, and W. Chłopicki, Eds. Tartu: ELM Scholarly Press, 2013, pp. 7-24.

[5] A. Gunarwan, Pragmatik: teori dan kajian Nusantara. Jakarta: Penerbit Universitas Atma Jaya, 2007.

[6] L. R. Horn and G. L. Ward, The handbook of pragmatics. Malden, Oxford: Blackwell, 2011.

[7] H. Kridalaksana, Kamus Linguistik. Jakarta: Gramedia Pustaka Utama, 2001.

[8] I. D. P. Wijana, "Implikatur Dalam Wacana Pokok," J. Hum., vol. 13, no. 3, pp. 215220, 2001.

[9] Z. K. Syaifudin, "Implikatur dan Kesantunan Positif Tuturan Jokowi dalam Talkshow Mata Najwa dan Implementasinya sebagai Bahan Ajar Bahasa Indonesia di SMK," $J$. Penelit. Hum., vol. 14, no. 1, pp. 55-70, 2017.

[10] P. Suratno, Masyarakat Jawa \& budaya barat: kajian sastra Jawa masa kolonial. Yogyakarta: Adi Wacana, 2013.

[11] Z. Abidin, "Representasi Nasionalisme dalam Film Nagabonar Jadi 2: Analisis Semiotika Roland Barthes Mengenai Representasi Nilai-Nilai Nasionalisme dalam Film Nagabonar Jadi 2,” J. Polit. Indones., vol. 2, no. 1, pp. 42-61, 2017. 